INTERNATIONAL JOURN AL OF RESEARCHES IN BIOSCIENCES, AGRICULTURE AND TECHNOLOGY (c) VISHWASHANTI MULTIPURPOSE SOCIETY (Global Peace Multipurpose Socie ty) R. No. MH-659/13 (N) www.vmsindia.org

\title{
SCREENING OF SOME MASS CULTURED CYANOPHYCEAN ALGAE FOR THEIR BIOCHEMI CAL COMPOSITION
}

\author{
A. K. Mohite \\ P. G. Dept. of Botany, R.B. N B. College Shrirampur Dist-Ahmednagar M. S. Pin 413709 \\ angadmohite65@gmail.com
}

\begin{abstract}
:
Five taxa of blue green algae viz. Nostoc coeruleum, N. entophytum, Phormidium fragile (Meneghini) Gomont, Tolypothrix tenuis (Kuetz.) Johs. Schmidt em. and Spirulina platensis (Nordst.) Geitler we re mass cultured using nutrient medium in laboratory. The dried powder of these algal samples was analysed for their biochemical constituents like proteins, total carbohydrates, lipids and phe nol content. The results obtained were expressed on percentage dry matter basis. The order of observed concentration amongst the m was total carbohydrates $>$ lipids $>$ proteins > phenols except Spirulina platensis and Phormidium fragile. Proteins were ranged from $4.46 \pm 0.27$ to $44.1 \pm 1.01 \%$, total carbohydrates $10.32 \pm 0.59$ to $28.24 \pm 0.88 \%$, lipids $1.26 \pm 0.26$ to $19.05 \pm 0.82$ and phenols were varie $d$ from minimum of $0.068 \pm 0.015$ to $1.06 \pm 0.108 \%$.

Keywords: Biochemical composition, mass cultured, blue green algae.
\end{abstract}

\section{Introduction}

The term algae cover a wide range from microscopic unicellular to a gigantic form of seaweed. Studies on taxonomy, ecology, physiology and other fundamental aspects we re carried out by number of workers from time to time enriching our knowledge of algae. The abundance and diversity of algae have made the m prime material for human use (Waaland, 1981). More than 213 species of algae are used as food in different countries of the world (Kiple, 2000).

A huge number of algal taxa are being used as human food from time immemorial. But the exploitation of marine and freshwater algae for nutritional and industrial purpose is primarily based on the biochemical constituents of these forms. Thus the biochemical composition of algae not only plays a key role in its metabolism but also decides its application. Studies on biochemical composition of seve ral marine algae have been carried out from Indian coast as well as abroad by many workers as are used as food, fodder, phycocolloid production, fertilizer and so on. Like macroalgae, microalgae are also rich in proteins, carbohydrates, amino acids, trace elements and vitamins (Waaland, 1981). Some microalgae like Spirulina, Chlorella, Nostoc, Anabaena etc are rich source of proteins and trace elements and the refore have been used as a safe source of food for centuries in some countries. Namikawa (1906), Clement et al. (1967), Durand-Chastle (1980), Vargas et al. (1998) and Hantouch and Hreeb (2003) studied biochemical composition of blue green algae. However, reports on biochemical composition of blue green algae are scanty (Rathore and
Kumar, 1993; Becker and Venkataraman, 1984). In this context, we have undertaken investigation on biochemical composition of some mass cultured blue green algae.

Materials and Methods:

Nostoc coeruleum, N. entophytum, Phormidium fragile and Tolypothrix tenuis were initially isolated from soils of Shrirampur tahsil. While a pure strain of Spirulina platensis was procured from Krishi Vidhyan Kendra (Pyrens), Bab hales hwar (Dist. Ahmednagar, M. S.)

These forms were mass cultured using BG 11 medium under aseptic conditions in laboratory at $28 \pm 2^{\circ} \mathrm{C}$ and illuminated with white fluorescent tubes. The best grown homogenous suspension of these algal mass was then filte red through Whatman filter paper, water drained material was then shade dried in the laboratory. Completely dried material was crushed with mortar and pestle to powder form. The fine powder of each alga was used for biochemical analysis.

Total protein content was determined with folin- ciocalteu reagent, with bovine albumen serum $\mathrm{V}$ as the standard by Lowry's method (Lowry et al., 1951). The total carbohydrate content was estimated by using anthrone reagent as per the method described in Sadashivam and Manickam (1996) using Dglucose as standard. Lipids were extracted and estimated by the procedure of Folch et al. (1957). While total phenols we re determined by the method of Farkas and Kirlay (1962). Species identification was done with the help of Desikachary (1959). 


\section{Results and Discussion}

The estimated concentrations of biochemical constituents were given in table -1 . Spirulina platensis $(28.24 \pm 0.88 \%)$ showed many folds greater total carbohydrate content than that of reported (9\%) by Becker and Venkataraman (1984) and also more than the estimated value for S. maxima (16-18\% and 13 $17 \%$ ) by Clement et al. (1967) and DurandChastel (1980), respectively. Total carbohydrate content of the two species of Nostoc, N. coeruleum and $N$. entophytum varied greatly. Both the species revealed comparatively less total carbohydrate content as compared to the reported value from $N$. phylloderma (59\%) by Namikawa (1906). Similarly, the estimated total carbohydrate content $(20.88 \pm 0.97 \%)$ in Phormidium fragile is not in agreement with the P. tenue (32\%) by Namikawa (1908). The total carbohydrate content in all the studied blue green algae except Nostoc coeruleum follows the range of $16 \%$ to $38 \%$ total carbohydrates by Vargas et al. (1998) for twelve strains of filamentous he te rocys tous, $\mathrm{N}_{2}$ fixing blue green algae .

The highest $44.1 \pm 1.01 \%$ protein content was recorded in Spirulina platensis and confirms the (46 to $50 \%$ proteins) findings of Becker and Venkataraman (1984). At the same time it appears less than that of (56 to $71 \%$ ) protein content from $S$. maxima by Clement et al. (1967) and Durand-Chastel (1980). Like to tal carbohydrates, protein content in two species of Nostoc also varied slightly. However, the protein content from two species of Nostoc is not in agreement with the estimated protein value (25\%) from $N$. phylloderma by Namikawa (1908). Whe reas, the pragmatic value $(9.29 \pm 0.42 \%)$ of protein content in Phormidium fragile is much closer to the reported value $(11 \%)$ from $P$. tenue by Namikawa (1908). The prote in content of only Spirulina platensis lies in the range of 37 to $53 \%$ proteins obtained for twelve strains of filamentous he te rocystous, $\mathrm{N}_{2}$ fixing blue green algae by Vargas et al. (1998), while all four remaining forms revealed far less proteins than this range.

Lipid content amongst studied blue green algae varied from $1.26 \pm 0.26 \%$ in Spirulina platensis to a maximum of $19.05 \pm$ $0.82 \%$ in $N$. coeruleum. In the present study, anticipated lipid content in $S$. platensis is slightly less than that of value $(3 \%)$ reported by Becker and Venkataraman (1984) in same species as well as Clement et al. (1967) from $S$. maxima (2-3\%). However, it greatly varies than the value $(6-7 \%)$ of lipid content noticed by Durand-Chastel (1980) from S. maxima. The lipid content noticed in both the two species was dissimilar and very much elevated than that of $N$. phylloderma (1\%) as studied by Namikawa (1908). While $P$. fragile exhibited $(4.18 \pm 0.69$ $\%)$ higher lipid content as compared with the results of Namikawa (1908) for P. tenue (1\%). However, only $N$. coeruleum and $N$. entophytum anticipated lipid composition that fits in the range of 8 to $13 \%$ reported by Vargas et al. (1998) from twelve filamentous, heterocystous strains of blue green algae.

The phenol content ranged from minimum of $0.068 \pm 0.015 \%$ in $P$. fragile to a maximum of $1.06 \pm 0.108 \%$ in S. platensis. Phenol content of all four algal species except $S$. platensis was observed to be identical.

The gross chemical composition of algae under investigation was calculated by adding the values of estimated chemical constituents and shown graphically (Plate 1) The topmost $74.66 \%$ gross chemical composition was observed in S. platensis while all remaining four studied blue green algal species exhibited identical gross chemical composition comparative ly very less than that of $S$. platen sis.

\section{Acknowledgements:}

Authors are thankful to the Principal, R. B. N. B. College, Shrirampur for encouragements and Principal, P. V. P. College, Pravaranagar for providing all facilities. Our thanks are also due to the University Grants Commission for award of teacher fellowship under FIP during $10^{\text {th }}$ plan.

Table 1. BIOCHEMICAL COMPOSITION OF BLUE GREEN ALGAE

\begin{tabular}{|c|c|c|c|c|c|}
\hline $\begin{array}{l}\text { Sr. } \\
\text { No. }\end{array}$ & Name of the Alga & $\begin{array}{c}\text { Prote ins } \pm \\
\text { SE }\end{array}$ & $\begin{array}{c}\text { Total } \\
\text { Carbohy- } \\
\text { drates } \pm \\
\text { SE }\end{array}$ & $\begin{array}{c}\text { Lipids } \pm \\
\text { SE }\end{array}$ & $\begin{array}{c}\text { Phenols } \pm \\
\text { SE }\end{array}$ \\
\hline 1 & Spirulia platensis (Nordst.) Geitler & $44.1 \pm 1.01$ & $28.24 \pm .88$ & $1.26 \pm 0.26$ & $1.06 \pm 0.108$ \\
\hline 2 & Nostoc entophytum Born et Flah & $8.26 \pm 0.52$ & $18.3 \pm 0.79$ & $10.2 \pm 0.61$ & $0.15 \pm 0.022$ \\
\hline 3 & Nostoc coeruleum Lyngbye ex Born et Flah. & $5.44 \pm 0.39$ & $10.32 \pm 0.59$ & $19.05 \pm 0.82$ & $0.075 \pm 0.009$ \\
\hline 4 & Phormidium fragile (Meneghini) Gomant & $9.29 \pm .42$ & $20.88 \pm 0.97$ & $4.18 \pm 0.69$ & $0.068 \pm 0.015$ \\
\hline 5 & $\begin{array}{l}\text { Tolypothrix tenuis (Kue tz.) Johs. Schmidt } \\
\text { em. }\end{array}$ & $4.46 \pm 0.27$ & $20.4 \pm 1.27$ & $6.1 \pm 0.84$ & $0.094 \pm 0.018$ \\
\hline
\end{tabular}

All the values were expressed on \% Dry weight basis. 
Plate I - Gross chemical composition of mass cultured blue green algae

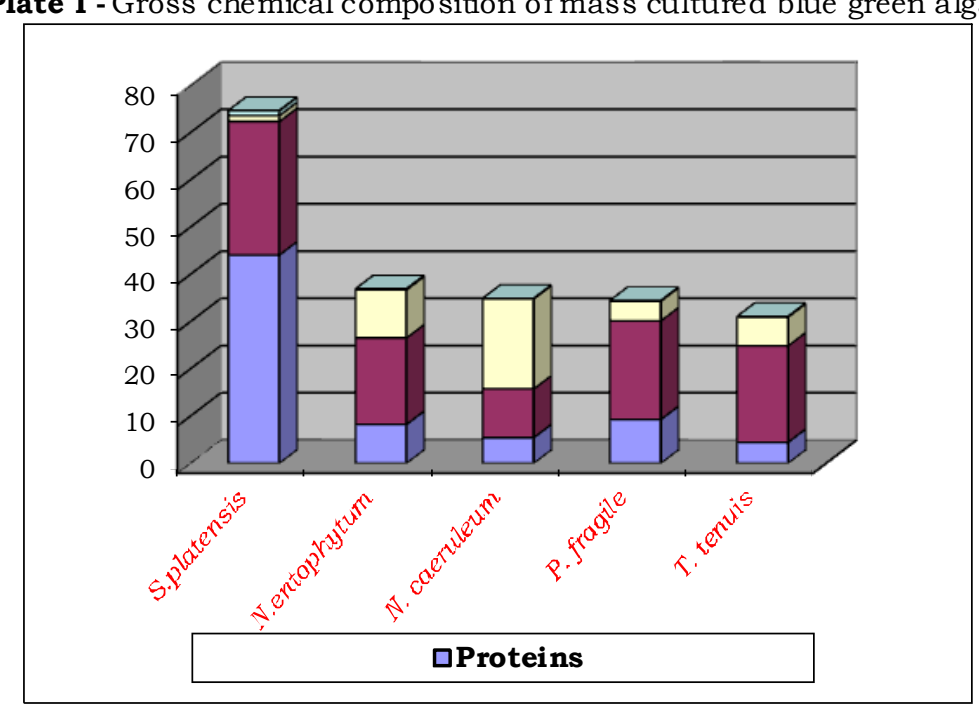

\section{Refer ences:}

Becker, E.W. and Venkataraman, L. V. 1984. Production and utilization of the blue-green alga Spirulina in India. Biomass, 4:105-125.

Clement, G., Giddey, C. and Merzl, R. 1967. Amino acid composition and nutritive value of the alga Spirulina maxima. Journal of the Science of food and Agriculture, 18:497-501.

Desikachary, T. V. 1959. Cyanophyta, Indian Council of Agriculture Research, New Delhi. Pp. 1-686.

Durand-Chaste1, H. 1980. Production and use of Spirulina in Mexico. In Algae biomass, eds. G. Shelef and C. J. Soeder, 51-64, Amsterdam.

Farkas, G. L. and Kiraly, Z. 1962. Role of phenolic compounds in the physiology of disease and disease resistance. Phytopathol., 44:105-150

Folch, J. M., Less, M. and Stoare-Stanley, G. H. 1956. A Simple method for the isolation and purification of total lipids from animal tissues. J. Biol. Chem., 226: 497-507.

Hantouch, A. A. and Hreeb, K. K. 2003. The biochemical composition of some micro-algal species isolated from the Shatt al-Arab river. Marina Mesopotamica, 18 (1): 1-8.

Kiple, K. F. 2000. Important vegetable supplements. In: The Cambridge World His tory of Food. Vol. 1. Cambridge University Press. Pp: 231-249.
Lowry, O. H., Rosebrough, N. J., Farr, A. L. and Randall, R. J. 1951. Protein measurement with Folin-phenol reagent. Jour. Biol. Chem., 193: 265-275.

Namikawa, S. 1906. Fresh water algae as an article of human food. Bulletin of the college of Agriculture, Tokyo Imperial University, 7: 123124.

Rathore, D. S. and Ashok Kumar. 1993. Protein, Lipid and carbohydrate content of three microalgae. Phykos, 32 (1-2): 9-12.

Sadashivam, S. and Manickam, A. 1996. In: Biochemical methods, 2nd ed. New Age International Publishers, New Delhi. Pp 256.

Vargas, M. A., Rodríguez, H., Moreno, J., Olivares, H., Del Campo, J. A., Rivas, J. and Guerrero, M. G. 1998. Biochemical composition and fatty acid content of filamentous nitrogen-fixing cyanobacteria. Journal of Phycology, 34(5): 812

Waaland, J. R. 1981. Commercial Utilization. In: Botanical monographs Vol. 17 "The Biology of Seaweeds". Eds. C. S. Lobban and M. J. Wynne, Blackwell scientific Publications, Oxford, London. 726-741. 